The Canadian Mineralogist

Vol. 40, pp. 637-650 (2002)

\title{
SELENIUM, TELLURIUM, ARSENIC AND ANTIMONY CONTENTS OF PRIMARY MANTLE SULFIDES
}

\author{
KéIKO H. HATTORI ${ }^{\S}$ \\ Department of Earth Sciences, University of Ottawa, Ottawa, Ontario K1N 6N5, Canada \\ SHOJI ARAI \\ Department of Earth Sciences, Kanazawa University, Kanazawa, 920-1192, Japan \\ D. BARRIE CLARKE \\ Department of Earth Sciences, Dalhousie University, Halifax, Nova Scotia B3H 3J5, Canada
}

\begin{abstract}
Sulfide phases in peridotitic mantle xenoliths from Ichinomegata in Japan, Nunivak Island in Alaska, and southern Africa occur as globular grains within silicate minerals, and along grain boundaries of silicate and oxide minerals. The morphology of the sulfide grains suggests that the sulfide liquid was not interconnected in the mantle, even within single samples. This is supported by compositional variations of sulfides. Proton-induced X-ray excitation (PIXE) micro-analyses of 53 sulfide grains larger than $20 \mu \mathrm{m}$ in diameter reveal a wide range of compositions: Se 21-280 ppm, S/Se 1120-18800; Te up to $103 \mathrm{ppm}, \mathrm{S} / \mathrm{Te}$ $2,600-31,000$; As up to $670 \mathrm{ppm}$, As/S up to $208 \times 10^{-5}$, and $\mathrm{Sb}$, up to $146 \mathrm{ppm}, \mathrm{Sb} / \mathrm{S}$ up to $37 \times 10^{-5}$. S/Se and Ni show an inverse correlation in the sub-arc xenoliths, suggesting preferential retention of Se in the mantle during partial melting. Sulfur is the most readily removed element, whereas Te is the most likely retained element in the residual mantle. This interpretation is consistent with low $\mathrm{S} / \mathrm{Se}$ values for sulfides from refractory mantle wedges compared to values for the primitive mantle, generally high $\mathrm{S} / \mathrm{Se}$ and $\mathrm{Se} / \mathrm{Te}$ values in basalts, and low $\mathrm{S} / \mathrm{Se}$ and $\mathrm{Se} / \mathrm{Te}$ in boninites compared to mid-ocean-ridge basalts. The evidence implies that $\mathrm{S} / \mathrm{Se}$ values of mantle-derived magmas may vary depending on the degree of partial melting and previous melting history in the source mantle. High concentrations of $\mathrm{As}$ and $\mathrm{Sb}$ in arc magmas are considered to be supplied from subducting slabs. Our data showing low levels of As and $\mathrm{Sb}$ in sulfides from sub-arc mantle suggest their fast removal from mantle wedges compared to the rate of supply of these elements from subducting slabs. Alternatively, these elements may be transported by a fluid phase from slabs to the site of partial melting without residing in the mantle.
\end{abstract}

Keywords: chalcophile elements, selenium, tellurium, arsenic, antimony, sulfides, mantle metasomatism, xenoliths, sub-arc mantle, subcontinental lithospheric mantle, subduction flux, recycling.

\section{SOMMAIRE}

Les phases sulfurées des xénolithes péridotitiques du manteau provenant de Ichinomegata au Japon, l'île de Nunivak, en Alaska, et de l'Afrique du Sud se trouvent sous forme de grains globulaires piégés à l'intérieur de grains silicatés, et le long de bordures de grains de silicates et d'oxydes. La morphologie des grains de sulfures fait penser que le liquide sulfuré ne faisait pas partie d'un réseau interconnecté dans le manteau, même dans le cas d'échantillons individuels. C'est ce que semble aussi montrer les variations en composition des sulfures. Ces compositions, obtenues par micro-analyse PIXE (excitation de rayons X par faisceau de protons) de 53 grains de sulfures dépassant une taille de $20 \mu \mathrm{m}$ en diamètre, définissent un intervalle important de variation: Se 21-280 ppm, S/Se 1120-18800; Te jusqu'à 103 ppm, S/Te 2,600-31,000; As jusqu'à 670 ppm, As/S atteignant $208 \times 10^{-5}$, et $\mathrm{Sb}$, jusqu'à $146 \mathrm{ppm}, \mathrm{Sb} / \mathrm{S}$ atteignant $37 \times 10^{-5}$. S/Se et Ni montrent une corrélation inverse dans les xénolithes provenant d'un milieu sub-arc, ce qui pourrait indiquer une conservation préférentielle du Se dans le manteau au cours d'une fusion partielle. Le soufre serait l'élément le plus facile à mobiliser, tandis que le Te serait le plus apte à demeurer dans le manteau résiduel. Cette interprétation concorde avec les faibles valeurs de $\mathrm{S} / \mathrm{Se}$ dans les sulfures provenant des biseaux réfractaires du manteau, par rapport au manteau primitif, ainsi que des rapports $\mathrm{S} / \mathrm{Se}$ et $\mathrm{Se} / \mathrm{Te}$ généralement élevés dans les basaltes, et faibles dans les boninites par rapport aux basaltes des rides océaniques. Le rapport $\mathrm{S} / \mathrm{Se}$ d'un magma dérivé du manteau varie donc en fonction du degré de fusion partielle et des événements de fusion antécédants de la source mantélique. Les concentrations élevées de As et Sb dans les magmas d'arcs insulaires résulteraient d'apports provenant de la croûte subductée. Nos données impliquant de faibles niveaux de $\mathrm{As}$ et $\mathrm{Sb}$ dans les sulfures du manteau en dessous d'arcs insulaires semblent indiquer une extraction rapide

§E-mail address: khattori@uottawa.ca 
à partir des biseaux mantéliques par rapport au taux d'addition de ces éléments par contributions des plaques lithosphériques subductées. En revanche, il est possible que ces éléments soient transportés efficacement par une phase fluide d'une plaque lithosphérique subductée au site de fusion partielle sans période de résidence dans le manteau.

(Traduit par la Rédaction)

Mots-clés: éléments chalcophiles, sélénium, tellurium, arsenic, antimoine, sulfures, métasomatose du manteau, xénolithes, manteau sub-arc, manteau lithosphérique subcontinental, flux de subduction, recyclage.

\section{INTRODUCTION}

The distribution and composition of sulfides in the mantle are not well known, but such information is relevant to two fundamental questions. First, the concentrations of siderophile elements in the mantle are greater than expected from equilibrium separation of the mantle from the core by several orders of magnitude, and the cause for this "overabundance" has been long debated (e.g., Sun 1985, Rama Murthy 1991, Palme 1999). Sulfides may contribute to this "overabundance" (Arculus \& Delano 1981) since they are rich in siderophile and chalcophile elements. Second, the enrichment of chalcophile elements in the mantle may in turn be associated with the formation of gold and base-metal deposits. Such metallic ore deposits are abundant in volcanic arcs, and the metals in the deposits may have been derived from subducting slabs via metasomatized mantle wedges (Sillitoe 1972). The heterogeneous distribution of such metal deposits in volcanic arcs may be related to localized enrichment of chalcophile elements in mantle wedges.

Previous studies of the behavior of siderophile and chalcophile elements in the mantle have been based on bulk analyses of mantle rocks (e.g., Jagoutz et al. 1979, Kurat et al. 1980, Jochum \& Hofmann 1997). Here, we use a micro proton-induced X-ray excitation probe (PIXE) to provide the first documentation of the concentrations of $\mathrm{As}, \mathrm{Sb}, \mathrm{Se}$, and Te in primary sulfides in xenoliths from mantle wedges, and in xenoliths in kimberlites derived from the subcontinental lithospheric mantle. Our data show a wide range of $\mathrm{Se}, \mathrm{Te}, \mathrm{As}$, and $\mathrm{Sb}$ concentrations, as well as $\mathrm{S} / \mathrm{Se}, \mathrm{S} / \mathrm{Te}, \mathrm{S} / \mathrm{As}$, and $\mathrm{S} / \mathrm{Sb}$ values in mantle sulfides. We relate these variations primarily to depletion by partial melting events in the mantle.

\section{SAMPLES}

Peridotitic xenoliths from Ichinomegata, Japan, were brought to the surface by explosive volcanic eruptions of tholeiitic basalt and calc-alkaline andesite $\sim 10,000$ years ago (Abe \& Arai 1993). The samples are predominantly lherzolite with minor harzburgite, and show equigranular to porphyroclastic textures. They represent a metasomatized, refractory mantle that provided calcalkaline magmas for construction of the Japanese arc (Kuno 1967, Takahashi 1986). Olivine is Mg-rich,
Fo88-91 in anhydrous samples and Fo83-86 in pargasiterich (10 vol.\%) samples. Spinel (0.1-5.6 modal \%) has a value (atomic basis) of $\mathrm{Cr} /(\mathrm{Cr}+\mathrm{Al})$ ranging from 0.1 to 0.5 (Abe \& Arai 1993). Hydrous metasomatism is expressed by the occurrence of pargasite (up to 20 vol.\%) and phlogopite. Pargasite is characterized by low $\mathrm{Ti}\left(<1.6\right.$ wt. \% $\left.\mathrm{TiO}_{2}\right)$ and commonly replaces subsolidus minerals such as pyroxene of symplectitic intergrowths and clinopyroxene lamellae in orthopyroxene (Arai 1986, Abe et al. 1992). Phlogopite occurs as clotted aggregates with pargasite-rich veinlets. Samples used for this study consist of harzburgite, pargasite spinel lherzolite, and phlogopite - pargasite spinel lherzolite (Table 1), and their mineral chemistry and textures are described in Abe et al $(1992,1998)$ and Abe \& Arai (1993).

Nunivak Island, $\sim 50 \mathrm{~km}$ west of the Alaskan coast, consists of olivine tholeiite flows and overlying alkali olivine basalts (Roden et al. 1984). The spatter cones and maars of alkali basalts contain abundant megacrysts of clinopyroxene, kaersutite, and anorthoclase, as well as peridotitic xenoliths. The peridotitic xenoliths show coarse-equant, coarse-tabular, and granuloblasticequant textures and include lherzolite and minor dunite, harzburgite, and pargasite-bearing pyroxenite (Francis 1976, 1978, Roden et al. 1984). The peridotitic xenoliths used for this study occur in basanites less than 1 million years old and include pargasite-bearing spinel lherzolite, with or without phlogopite veinlets, and a garnet pyroxenite (Table 1). The xenoliths sampled commonly contain abundant fluid inclusions and also show evidence of incipient melting (Francis 1976). A lherzolite sample (10001) contains "glass" that replaces hornblende and now consists of relict pargasite and fine aggregates of clinopyroxene and phlogopite. Garnet pyroxenite (sample 13008) is different from the rest of the samples. It represents a cumulate formed from a melt that solidified in the mantle, as pyroxenites in obducted mantle rocks (Kumar et al. 1996). Peterson \& Francis (1977) described a megacryst of chromian diopside containing immiscible sulfide spherules of a mixture of pyrrhotite and chalcopyrite, and fluid inclusions along growth planes of the host diopside. Unfortunately, these sulfide grains are too small, less than $10 \mu \mathrm{m}$ across, for PIXE analysis, so were not used for this study. Overall, the Nunivak samples are similar to those from Ichinomegata in that they appear to represent rocks from a refractory mantle wedge that has undergone hydrous 
TABLE 1. LIST OF SAMPLES SELECTED FOR A STUDY OF PRIMARY MANTLE SULFIDES

\begin{tabular}{|c|c|c|c|c|c|}
\hline & Location & & Primary minerals and their composition** & Fo & $\mathrm{CrH}$ \\
\hline 014 & Ichinomegata & Phl Prg harzburgite & $\begin{array}{l}\text { Ol (51.1), Opx (32.4), Cpx (0.8), } \\
\text { Spl (0.9), Prg (14.1), Phl (0.3) }\end{array}$ & 83.7 & 0.27 \\
\hline 015 & Ichinomegata & Spl Prg lherzolite & $\begin{array}{l}\text { Ol (5l.5), Opx (26.6), Cpx (14.5), } \\
\operatorname{Spl}(2.1), \operatorname{Prg}(4.0)\end{array}$ & 88.5 & 0.13 \\
\hline 538 & Ichinomegata & Prg Spl lherzolite & $\begin{array}{l}\text { Ol (50) Opx (20), Cpx (15), Spl (5), } \\
\text { Prg (10) }\end{array}$ & 88.8 & 0.11 \\
\hline 638 & Ichinomegata & $\begin{array}{l}\text { Harzburgite, } \\
\text { rare Prg }\end{array}$ & $\begin{array}{l}\text { Ol (51.8), Opx (26.6), Spl (1.8), } \\
\text { Cpx (10.0), Prg (0.9), Symp(Pl-Px) (8.0) }\end{array}$ & 90.0 & 0.14 \\
\hline 10001 & Nunivak & $\begin{array}{l}\text { Coarse equant } \\
\text { spinel lherzolite } \\
\text { containing devitri- } \\
\text { fied "glass"* }\end{array}$ & $\begin{array}{l}\text { Ol (35), Cpx (35), Opx (15), Spl (8), } \\
\text { Prg (5), Phl (2) } \\
0.90<\mathrm{Mg} \sharp(\mathrm{Cpx})<0.93 \\
\mathrm{Mg}(\text { Opx) } 0.90\end{array}$ & $\begin{array}{r}89- \\
91\end{array}$ & \\
\hline 10057 & Nunivak & $\begin{array}{l}\text { Coarse, weakly foliated } \\
\text { spinel lherzolite }\end{array}$ & $\begin{array}{l}\text { Ol (50), Cpx (25), Opx (20), Spl (4), } \\
\text { Prg (1), Mg\#(Cpx) 0.91, } \\
\text { Mg\#(Opx) } 0.90\end{array}$ & 90 & \\
\hline 13008 & Nunivak & Grt pyroxenite & $\begin{array}{l}\text { Cpx (85), Ol (8), Grt (5), Spl (1), } \\
\text { Prg (1), sulfides (3), Mg\#(Cpx) } 0.73\end{array}$ & & \\
\hline FS & Frank Smith & $\begin{array}{l}\text { Cpx megacryst with } \\
\text { oriented inclusions }\end{array}$ & $\begin{array}{l}\text { Cpx (84), lamellae of Ilm (15), } \\
\text { sulfide blebs }(1 ; \mathrm{Po}, \mathrm{Pn}, \mathrm{Djr}) \\
\mathrm{Cpx}\left(\mathrm{Mg}_{0.839} \mathrm{Fe}_{0.057} \mathrm{Cr}_{0.013} \mathrm{Si}_{1.97} \mathrm{Al}_{0.093} \mathrm{O}_{6}\right)\end{array}$ & & \\
\hline DBC-47 & Kimberley & $\begin{array}{l}\text { Grt harzburgite } \\
\text { containing Cr-rich } \\
\left(1.9 \text { wt } \% \mathrm{Cr}_{2} \mathrm{O}_{3}\right) \mathrm{Di}\end{array}$ & $\begin{array}{l}\mathrm{Ol}+\mathrm{Opx}(85), \mathrm{Cpx}(<5), \mathrm{Grt}(5-10) \\
\mathrm{Phl}(1) ; \mathrm{Mg} \text { (Opx) } 0.940, \mathrm{Mg} \text { (Phl) } \\
0.95, \mathrm{Grt}(73.4 \% \text { Prp, } 11.2 \% \text { Uvr, } 8 \% \\
\text { Alm, } 6.1 \% \mathrm{Adr}, 0.6 \% \mathrm{Sps})\end{array}$ & $\begin{array}{r}92- \\
93\end{array}$ & \\
\hline PTH516 & Lesotho & $\begin{array}{l}\text { Phl herzolite } \\
\text { containing Cr-rich } \\
\left(2.6-3.2 \mathrm{wt}^{2} \% \mathrm{Cr}_{2} \mathrm{O}_{3}\right) \mathrm{Di}\end{array}$ & $\begin{array}{l}\text { Ol+ Opx (75), Cpx (10), Phl (14), } \\
\text { Spl (1); Mg\# (Opx): 0.931; Mg\# (Phl): } \\
0.944\end{array}$ & $\begin{array}{r}92- \\
93\end{array}$ & $\begin{array}{r}0.86 \\
-0.89\end{array}$ \\
\hline DBC-L & Lesotho & $\begin{array}{l}\text { Grt harzburgite } \\
\text { containing } \mathrm{Cr}_{-} \text {-rich } \mathrm{Di} \\
\left(\sim 1.8 \text { wt\% } \mathrm{Cr}_{2} \mathrm{O}_{3}\right)\end{array}$ & $\begin{array}{l}\mathrm{Ol}+\text { Opx (90), Cpx (5), Grt (5); } \\
\text { Mg\# (Opx): 0.929, Mg\# (Cpx): } 0.952 \text {, } \\
\text { Grt (67.2\% Prp, } 15.1 \% \text { Uvr, } 12.8 \% \\
\text { Alm, } 4.1 \% \text { Adr } 0.8 \% \text { Sps) }\end{array}$ & $\begin{array}{r}92 \\
93\end{array}$ & \\
\hline
\end{tabular}

\footnotetext{
Symbols: Cpx: clinopyroxene, Djr: djerfisherite, Grt: garnet, Ilm: ilmenite, Ol: olivine, Opx: orthopyroxene, Phl: phlogopite, Pn: pentlandite, Po: pyrrhotite, Prg: pargasite, Spl: spinel, Symp $(\mathrm{Pl}-\mathrm{Px})=$ symplectite of spinel + pyroxene Components of garnet: Adr: andradite, Alm: almandine, Prp: pyrope, Sps: spessartine, Uvr: uvarovite. * Glass is now composed of fine aggregates of clinopyroxene and relict pargasite.

** $\mathrm{Cr} \#=$ atomic $\mathrm{Cr} /(\mathrm{Cr}+\mathrm{Al})$ in chromian spinel, $\mathrm{Mg} \#=$ atomic $\mathrm{Mg} /\left(\mathrm{Mg}+\mathrm{Fe}^{2+}\right)$.

The modal proportion of the primary minerals is reported in parentheses.
}

metasomatism. The samples from Nunivak appear to have undergone more advanced degrees of hydrous alteration.

The samples from kimberlites in southern Africa include: a diopside megacryst (sample DBC-FS) from the Frank Smith mine, South Africa (Clarke et al. 1977), containing exsolution lamellae of magnesian $(\sim 10 \mathrm{wt} \%$ $\mathrm{MgO})$ ilmenite and blebs of sulfide, including pyrrhotite, pentlandite, and djerfisherite, $\mathrm{K}_{6}(\mathrm{Cu}, \mathrm{Fe}$, $\mathrm{Ni})_{25} \mathrm{~S}_{26} \mathrm{Cl}$; a coarse-grained, granular, pyrope garnet harzburgite nodule from the Bultfontein Floors, Kimberley, South Africa (sample DBC-47); a coarsegrained, granular, pyrope harzburgite with minor chromian diopside (<5 vol.\%), and wide, fine-grained kelyphitic rims on the garnet from Pipe 200, Lesotho (sample DBC-L) (Carswell et al. 1979, Mitchell et al. 1980), and a medium-grained, granular lherzolite (sample PTH-516) from Pipe 200, Lesotho, that appears to be the metasomatized equivalent of a garnet lherzolite in which coarse-grained clusters of chromian diopside, phlogopite, and magnesian chromite have replaced garnet (Schandl 1980). Olivine in all samples is Mgrich, ranging from $\mathrm{Fo}_{91.9}$ to $\mathrm{Fo}_{93.2}$, and $\mathrm{Ni}$-rich, ranging from 2000 to $4500 \mathrm{ppm} \mathrm{Ni}$, confirming the highly refractory nature of the source, subcontinental lithospheric mantle underlying the Kaapvaal craton.

\section{Analytical Methods}

Major compositions of minerals were determined using a JEOL 6400 digital SEM equipped with a $40^{\circ}$ take-off angle and a Link X-ray analyzer. Analytical conditions included a beam size $0.25 \mu \mathrm{m}$ in diameter, an accelerating potential of $20 \mathrm{kV}$, a current of $0.8 \mathrm{nA}$ and a counting time of 140 to $200 \mathrm{~s}$. The following standards were used for the analysis of sulfides; pyrite (Fe, S), chalcopyrite $(\mathrm{Cu})$, Ni metal $(\mathrm{Ni})$, Co metal $(\mathrm{Co})$, and $\mathrm{ZnS}(\mathrm{Zn})$; oxide standards were used: $\mathrm{SiO}_{2}(\mathrm{Si})$, 
$\mathrm{Al}_{2} \mathrm{O}_{3}(\mathrm{Al}), \mathrm{MgO}(\mathrm{Mg})$, chromite $(\mathrm{Cr}), \mathrm{MnTiO}_{3}(\mathrm{Mn}$, $\mathrm{Ti})$, and hematite $(\mathrm{Fe})$. Detection limits are $\sim 0.05 \mathrm{wt} \%$. The levels of selected trace elements in the sulfides were determined using a micro proton-induced X-ray excitation probe (PIXE) at the University of Guelph. Operating conditions were: a proton energy of $3 \mathrm{MeV}$, a specimen current of $\sim 4$ to $8 \mathrm{nA}$, a counting time of 1,000 to $1,200 \mathrm{~s}$, and a beam size of $4 \times 5 \mu \mathrm{m}$. The proton beam has an angle of $45^{\circ}$ to the specimen and excites elements up to a depth of $\sim 20 \mu \mathrm{m}$. The detection limit of each element is equal to three standard deviations on the mean background measured on both sides of the peak of the element, and the background values vary depending on the composition. Accordingly, detection limits of a given element are different among different grains. Detailed operating conditions and analytical procedures were described by Cabri et al. (1984) and Campbell \& Czamanske (1998). To monitor the quality of the analysis, $\mathrm{Mg}, \mathrm{Al}, \mathrm{Si}$, and $\mathrm{S}$ were simultaneously determined. Data with totals of $(\mathrm{FeS}+$ $\mathrm{NiS}+\mathrm{CuS}+\mathrm{CoS}$ ) greater than $90 \mathrm{wt} \%$ were used, and subsequently normalized to $100 \mathrm{wt} \%$. Typical analytical precision and accuracy are believed to be better than $10 \%$ for most elements, based on replicate analyses of a natural pyrrhotite standard.

Sulfide grains are minor constituents in our samples and rarely exceed more than 1 vol. $\%$, except in the case of a garnet clinopyroxenite from Nunivak Island. Furthermore, most sulfide grains are very small $(<10 \mu \mathrm{m})$. To obtain reliable trace-element data using the PIXE, we chose sulfide grains greater than $20 \mu \mathrm{m}$ in diameter because the proton beam excites elements up to $\sim 20 \mu \mathrm{m}$ below the surface. This size restriction may have resulted in a potential bias in the data, although there are no apparent differences between large and small grains.

\section{RESULTS}

\section{Sulfide occurrences}

Most sulfide inclusions in ultramafic rocks are globular in shape, reflecting their former liquid state at mantle temperatures $\left(>1000^{\circ} \mathrm{C}\right)$. On cooling, they probably first crystallized as sulfide solid-solutions, and at a lower temperature, unmixed to form various proportions of pyrrhotite, pentlandite, chalcopyrite, heazlewoodite and magnetite (Table 2). These exsolution products form blebs, lamellae (less than several $\mu \mathrm{m}$ ), and irregularly shaped phases. We have classified our samples into four types, based on the morphology of the sulfides, and the occurrences are tabulated in Table 2.

Type 1. Isolated spherical grains enclosed within silicate minerals (Figs. 1a, 1b).

Type 2. Isolated globular grains [up to $\sim 100 \mu \mathrm{m}$ in diameter (Fig. 1c)] not hosted by silicates or oxides, but most commonly occurring at triple junctions of silicate minerals.
Type 3. Rare isolated angular grains along grain boundaries of silicate minerals.

Type 4. Discontinuous veinlets of sulfides along grain boundaries of silicate minerals. This type of sulfide is not common and occurs only in spinel lherzolite from Nunivak Island (sample 10057; Fig. 1d). The veinlets, 20-30 $\mu \mathrm{m}$ wide, along silicate grain-boundaries, consist of a pyrrhotite matrix with exsolved chalcopyrite, pentlandite, and magnetite (Fig. 1d). The occurrence of exsolved sulfide phases (Fig. 1e) suggests that the veinlets are a high-temperature product. Magnetite can be an exsolution product because natural sulfide liquids can contain significant concentrations of oxygen (up to $14 \mathrm{wt} \%$ O; Francis 1990, Roy-Barman et al. 1998, Rose \& Brenan 2001). The composition of the veinlets (Table 2, grain F, anal. 127) is similar to that of the sulfide grains enclosed in olivine and clinopyroxene in the sample, supporting the idea that these veinlets represent rare channeled sulfide liquid in the mantle, as has been postulated by Gaetani \& Grove (1999).

Serpentinized samples show destabilization of primary sulfides and the formation of secondary sulfides. Altered sulfides have low reflectivity caused by the formation of fine-grained hematite and Fe hydroxides. The secondary pyrrhotite forms narrow films, less than $10 \mu \mathrm{m}$ wide, along grain boundaries of silicates. The compositions of such secondary sulfides are not included in the results.

\section{Selenium and tellurium}

All analyzed grains contain detectable amounts of Se (Table 2), and the weight ratios of S to Se range from 1,120 to 18,800 (Fig. 2a). The ratios from individual samples are clustered, approximating chemical equilibrium, except for sample 10001. The low $\mathrm{S} / \mathrm{Se}$ values, $\sim 1,500$, occur in sulfides in a spinel harzburgite (sample 638) from Ichinomegata, which represents the most refractory sample judging from the lithology and high level of $\mathrm{Mg}$ in olivine (Fog0). The values of $\mathrm{S} / \mathrm{Se}, \sim 1500$, are low compared to those of primitive mantle $(3,300$; McDonough \& Sun 1995) and CI chondritic meteorites ( 2,540; Dreibus et al. 1995). Sulfides from the metasomatized kimberlite nodules have $\mathrm{S} / \mathrm{Se}$ values lower than the primitive mantle, the Frank Smith discrete nodule matches primitive mantle, and the garnet lherzolite from Kimberley has $\mathrm{S} / \mathrm{Se}$ greater than primitive mantle.

Only five sulfide grains from mantle wedges, and four sulfide grains from the subcontinental lithosphere, contain concentrations of Te above the detection limit ( 20 ppm).

\section{Arsenic and antimony}

Many sulfide grains in our samples show detectable amounts of As. High As contents occur in sulfides from peridotite nodules in kimberlites, with several grains containing more than 200 ppm (Fig. 3). Similarly, high 
TABLE 2. TRACE-ELEMENT CONCENTRATIONS IN PRIMARY MANTLE SULFIDES

\begin{tabular}{|c|c|c|c|c|c|c|c|c|c|c|c|c|}
\hline section & \multicolumn{12}{|c|}{$\begin{array}{c}1300813008130081300813008130081300813008130081300813008130081300813008 \\
-Z\end{array}$} \\
\hline loc. $(\alpha)$ & NunI & NunI & NunI & I NunI & I NunI & NunI $N$ & NunI NunI & I NunI & NunI & NunI 1 & NunI NunI & NunI \\
\hline grain & BA & $\mathrm{BC}$ & $\mathrm{AB}$ & $\mathrm{CA}$ & $C B$ & $\mathbf{Z}$ & $\mathrm{Y} \quad \mathrm{X}$ & $\mathbf{J}$ & F & $\mathrm{K}$ & L $\quad X$ & $\mathbf{H}$ \\
\hline anal. & 5 & 7 & 11 & 13 & 14 & 16 & 17 & 40 & 41 & 44 & 47 & 48 \\
\hline phase $(\boldsymbol{\beta})$ & Po & Po & $\mathrm{Po}$ & Po & Po & Po & Po & Po & Po & Po & Po $\quad P_{0}$ & Po \\
\hline occurrence $(\chi)$ & $\begin{array}{c}\text { Spl } \\
-\mathrm{Cpx}\end{array}$ & Cpx & i. $S p$ & $\mathrm{Cpx}$ & i. $\mathbf{C p x}$ & $\begin{array}{c}\mathrm{Cpx} \\
-\mathrm{OI}\end{array}$ & Ol i.Cpx & $x \quad$ i.OI & i. $\mathrm{Cpx}$ & $\begin{array}{c}\text { Spl } \\
-\mathrm{Cpx}\end{array}$ & Cpx $\quad \underset{-\mathrm{Cpx}}{\mathrm{Spl}}$ & i.Ol \\
\hline shape $(\delta)$ & $\mathrm{S}$ & A-R & S & $\mathrm{S}$ & $\mathrm{S}$ & $\mathrm{S}$ & $S$ & S & A & $\mathrm{R}$ & $\mathrm{R}$ & $\mathbf{S}$ \\
\hline $\mathrm{Ni} w t \%$ & 1.13 & 2.12 & 2.09 & 2.29 & 1.72 & $1.45 \quad 1$ & $\begin{array}{ll}1.82 & 2.13\end{array}$ & 2.63 & 2.13 & 2.06 & $2.01 \quad 2.09$ & 2.28 \\
\hline As ppm & 24 & $<4$ & 44 & 6 & $<9$ & 14 & $? 4$ & 0 & $<4$ & $? 6$ & $<5$ & $<6$ \\
\hline $\mathrm{Se}$ & 21 & 60 & 27 & 32 & 21 & 30 & 23 & 24 & 23 & 24 & 33 & 43 \\
\hline $\mathrm{Sb}$ & 79 & $<9$ & $<10$ & 11 & $<10$ & $<8$ & $<9$ & $<16$ & $<18$ & $<16$ & $<15<17$ & $<16$ \\
\hline $\mathrm{Te}$ & $? 9$ & 12 & $? 9$ & $<11$ & $<11$ & $<11$ ? & $? 20<10$ & $<20$ & $<22$ & $<21$ & $<21<20$ & $<20$ \\
\hline section & 10001 & 10001 & 10001 & 11001 & 1001 & 1000110 & 100571005 & 5710057 & $7 \quad 014$ & 15 & $015 \quad 015$ & 538 \\
\hline $\operatorname{loc}(\boldsymbol{\alpha})$ & Nunl & NunI & NunI & Nunl & NunI & NunI N & NunI NunI & I NunI & Ichi & Ichi & Ichi Ichi & Ichi \\
\hline grain & $\mathrm{CA}$ & $\mathrm{CB}$ & EA & $\mathrm{EB}$ & F & A & EA EB & $\mathrm{F}$ & D & $\mathrm{AA}$ & $\mathrm{AB} \quad \mathrm{AC}$ & B \\
\hline anal. & 23 & 24 & 26 & 64 & 63 & 25 & $125 \quad 126$ & 127 & 19 & 20 & 61 & 49 \\
\hline phase $(\beta)$ & Po & Po & Po & Po & $\mathrm{Pn}$ & Po & $\mathrm{Pn} \quad \mathrm{Pn}$ & $\mathrm{Pn}$ & Pn & $\mathrm{Pn}$ & $\mathrm{Pn}$ & Pn \\
\hline occurrence $(\chi)$ & i. $\mathrm{Cpx}$ & i.Cpx & i.Opx & i.Opx & $\mathrm{Ol}$ & $\mathrm{Ol}-\mathrm{M}$ & Ol $\begin{array}{c}\mathrm{Ol} \\
-\mathrm{Cpx}\end{array}$ & $\mathrm{Ol}$ & i.Ol & $\begin{array}{c}\mathrm{O} 1 \\
\mathrm{Cpx}\end{array}$ & Opx Opx & i.Cpx \\
\hline shape ( 8 ) & $\mathbf{S}$ & $\mathbf{S}$ & $\mathrm{S}$ & $\mathbf{R}$ & A & A & $\mathrm{R}-\mathrm{A} \quad \mathrm{R}$ & A & $S$ & R-A & $\mathbf{R}$ & $\mathrm{S}$ \\
\hline $\mathrm{Ni} w t \%$ & 2.86 & 2.39 & 3.30 & 8.73 & 11.9 & $3.31 \quad 7$ & $19.2 \quad 11.6$ & 21.8 & $10.4 \quad 1$ & 14.31 & $14.14 \quad 14.3$ & 16.1 \\
\hline As ppm & $<3$ & $? 4$ & $<3$ & $<4$ & 0 & $<2$ & $<9$ & $<8$ & 10 & 35 & $<6$ & $<6$ \\
\hline $\mathrm{Se}$ & 116 & 117 & 59 & 240 & 182 & 99 & 129 & 138 & 145 & 170 & $158 \quad 172$ & 280 \\
\hline $\mathrm{Sb}$ & $<9$ & $<10$ & 7 & $<23$ & $<17$ & 9 & $<14$ & $<13$ & $<13$ & 146 & $<17<16$ & $<18$ \\
\hline $\mathrm{Te}$ & 20 & $<12$ & $<10$ & 103 & $<23$ & $<14$ & 24 & 30 & 18 & 20 & $<23<20$ & $<21$ \\
\hline section & 538 & 538 & 538 & 538 & 538 & $538 \quad 6$ & $\begin{array}{ll}638 & 638\end{array}$ & $\mathrm{FC}$ & $\mathrm{FC}$ & FC & FC & FC \\
\hline loc. $(\alpha)$ & Ichi & Ichi & Ichi & Ichi & Ichi & Ichi I & Ichi Ichi & Frank & Frank F & Frank F & Frank Frank & Frank \\
\hline grain & $\mathrm{F}$ & $B-E$ & $\mathrm{EA}$ & EB & $\mathrm{HA}$ & $\mathrm{HB}$ & A & A & A & A & A $C$ & \\
\hline anal. & 50 & 51 & 52 & 53 & 54 & 55 & 66 & 33 & 34 & 35 & 38 & 39 \\
\hline phase $(\beta)$ & Pn & $P_{n}$ & $\mathrm{Pn}$ & Pn & Pn & $\mathrm{Pn}$ & $\mathrm{Pn}$ & $\mathrm{Pn}$ & $\mathrm{Dj}_{\mathrm{r}}$ & $\mathrm{Pn}$ & $\mathrm{Po} \mathrm{Po}+\mathrm{Pn}$ & $\mathrm{Pn}$ \\
\hline occurrence $(\chi)$ & OI & Ol & $\mathrm{OI}$ & $\mathrm{O} 1$ & O1 & $\mathrm{O} \quad \mathrm{O}$ & Opx i.Opx & $x$ i. $\mathrm{Cpx}$ & i.Cpx i. & i.Cpx i. & i.Cpx i.Cpx & i. $\mathrm{Cpx}$ \\
\hline & $-C p x$ & $-\mathrm{Cpx}$ & & $-\mathrm{Cpx}$ & & & & & & & & \\
\hline shape (ס) & $\mathrm{S}$ & $\mathbf{R}$ & $\mathbf{R}$ & $\mathrm{R}$ & $\mathbf{R}$ & $\mathbf{R}$ & $\mathbf{R}$ & $\mathbf{R}$ & $\mathrm{R}$ & $\mathbf{R}$ & $\mathbf{R}$ & $\mathbf{A}$ \\
\hline $\mathrm{Ni} w t \%$ & 18.92 & 15.06 & 15.17 & 15.87 & 14.86 & $15.23 \quad 13$ & 13.8421 .01 & 127.95 & 15.781 & 13,66 & $0.14 \quad 0.39$ & 19.17 \\
\hline As ppm & 7 & 6 & 6 & $<5$ & $<6$ & 28 & $<5$ & 8 & 11 & 13 & 15 & $<7$ \\
\hline $\mathrm{Se}$ & 189 & 217 & 200 & 229 & 222 & $216 \quad 1$ & $194 \quad 255$ & 103 & 113 & 129 & $111 \quad 101$ & 111 \\
\hline $\mathrm{Sb}$ & $<15$ & $<17$ & $<17$ & $<14$ & $<18$ & $<16<$ & $<17<16$ & $<18$ & $<18<$ & $<16<$ & $<16<15$ & $<18$ \\
\hline $\mathrm{Te}$ & $<21$ & $<25$ & 38 & 35 & $<21$ & $<20<$ & $<22<24$ & $<18$ & $<24$ & $<23<$ & $<22<21$ & $<22$ \\
\hline section & PTH & & TH & PTH & PTH & PTH & DBC & DBC & DBC & $\mathrm{DBC}$ & $\mathrm{DBC}$ & DBC \\
\hline & 516 & 51 & 16 & 516 & 516 & 516 & 47 & 47 & 47 & $-\mathrm{L}$ & $-\mathrm{L}$ & $-\mathrm{L}$ \\
\hline $\operatorname{loc}(\alpha)$ & Les. & Le & es. & Les. & Les. & Les. & Kimb. & Kimb. & Kimb. & Les. & Les. & Les. \\
\hline grain & B & C. & $\mathrm{A}$ & $\mathrm{CB}$ & D & $\mathrm{E}$ & A & $\mathrm{B}$ & C & A & A & A \\
\hline anal. & 106 & 10 & 08 & 109 & 110 & 112 & 116 & 117 & 119 & 120 & 121 & 122 \\
\hline phase $(\beta)$ & $\mathrm{Pn}$ & $\mathrm{Pr}$ & $\mathrm{n}$ & $\mathrm{Pn}$ & $\mathrm{Pn}$ & $\mathrm{Pn}-\mathrm{Ccp}$ & $\mathrm{cp} \mathrm{Hz}-\mathrm{Pn}$ & $\mathrm{Hz}-\mathrm{Pn}$ & $\mathrm{Hz}-\mathrm{Pn}$ & $\mathrm{Pn}$ & $\mathrm{Ccp}-\mathrm{Po}_{\mathrm{o}}$ & Pn \\
\hline occurrence $(\chi)$ & i.Ol & & $\mathrm{Dl}$ & $\mathrm{OI}$ & $\mathrm{Ol}$ & Ol & $\mathrm{Ol}$ & ol & OI & i.OI & i.Ol & i. 01 \\
\hline shape $(\delta)$ & A & & A & A & $\mathbf{R}$ & $\mathrm{R}$ & A & $\mathbf{R}$ & $\mathbf{R}$ & $\mathbf{S}$ & $\mathbf{S}$ & $\mathbf{S}$ \\
\hline Ni wt $\%$ & 27.3 & 35 & 5.3 & 39.2 & 28.8 & 35.9 & 47.1 & 55.9 & 56.7 & 18.7 & 7.1 & 17.0 \\
\hline As ppm & 12 & 48 & 80 & 670 & 34 & 240 & 29 & 54 & 52 & $<9$ & $<9$ & 14 \\
\hline $\mathrm{Se}$ & 130 & 12 & 20 & 110 & 32 & 180 & 26 & 34 & 52 & 180 & 160 & 170 \\
\hline $\mathrm{Sb}$ & $<11$ & 28 & 28 & 73 & $? 12$ & 29 & $<14$ & $<12$ & $<13$ & $<14$ & $<14$ & $<15$ \\
\hline $\mathrm{Te}$ & $<16$ & & 44 & 24 & $<15$ & $<21$ & $<15$ & $<14$ & 16 & $<19$ & $<20$ & 55 \\
\hline
\end{tabular}

The PIXE beam excites a large area, and the results represent the weighted average of the area of the analysis. Therefore, the data likely represent the composition of the whole grain.

$\alpha$ : loc: location; Ichi: Ichinomegata, NunI: Nunivak Island, Frank: Frank Smith kimberlite, Les : Lesotho, Kimb.: Kimberley.

$\beta$ : dominant sulfide phases: Ccp: chalcopyrite, Djr: djeffisherite, $\mathrm{Hz}$ : heazlewoodite, $\mathrm{Pn}$ : pendlandite, Po: pyrrhotite.

$\chi$ : $\mathrm{i}$.: enclosed in mineral followed by “ $\mathrm{i}$ ”, Cpx: clinopyroxene, $\mathrm{M}$; melt (aggregate of $\mathrm{Cpx}$ ), Ol: olivine, Opx: orthopyroxene, Spl: chromian spinel.

$\delta$ : shape; A: portion of outer shape is angular, $\mathbf{R}$ : well rounded, but not spherical, $\mathbf{S}$ : spherical. 

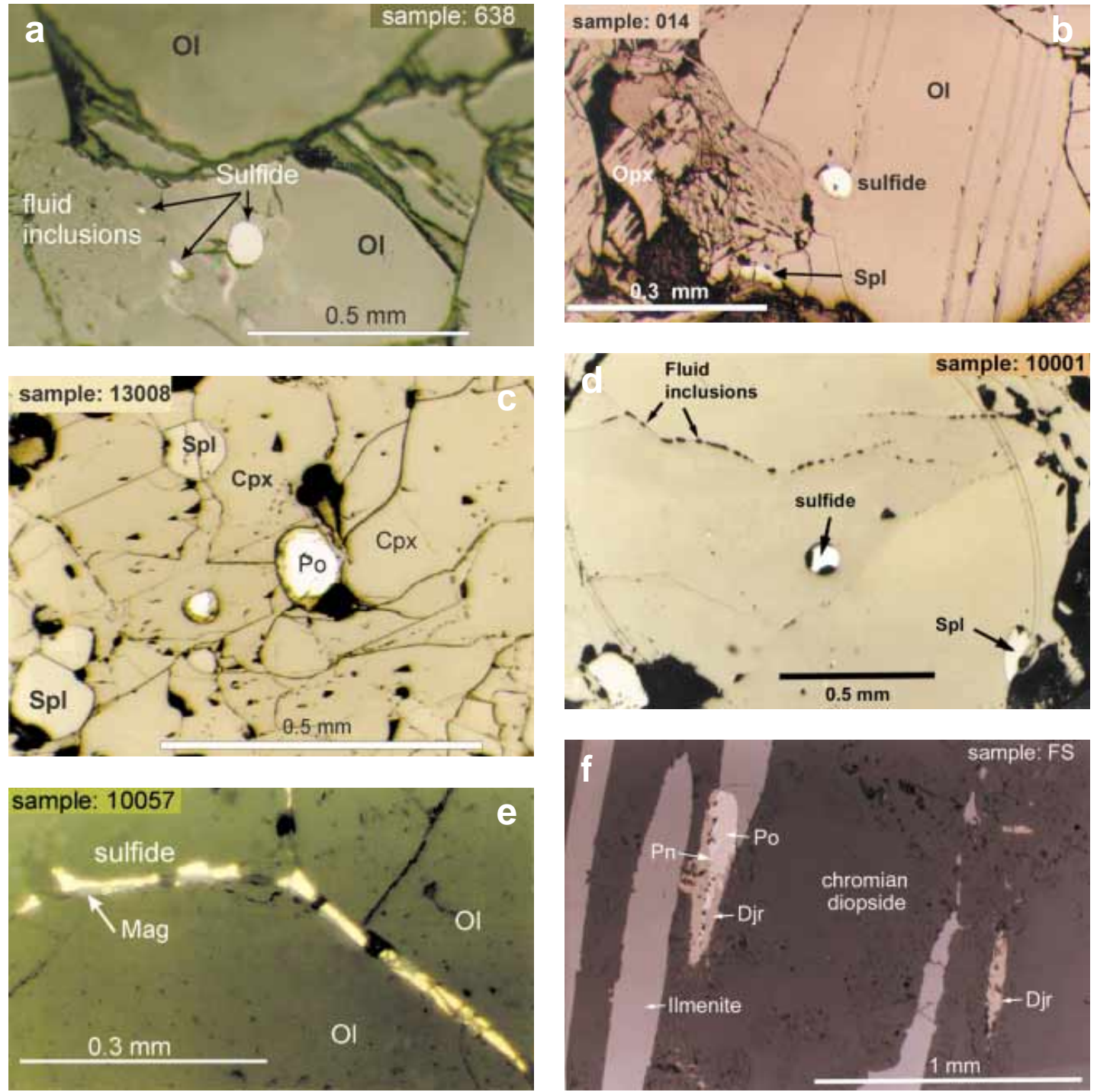

FIG. 1. Photomicrographs showing the mode of occurrence of sulfide grains, taken under reflected light. a. Spherical sulfide grain enclosed in olivine (Ol) in harzburgite (sample 638) from Ichinomegata, Japan. The sulfide is predominantly pentlandite. The olivine ( $\left.\mathrm{FO}_{90.0}\right)$ contains abundant fluid inclusions. b. Sulfide grain enclosed in olivine $\left(\mathrm{Fo}_{83.4}\right)$ in spinel lherzolite (sample 014) from Ichinomegata, Japan. The sulfide is pentlandite and pyrrhotite. Ol: olivine, Opx: orthopyroxene, Spl: chromian spinel c. Globular sulfide grain along grain boundaries of clinopyroxene (Cpx) and olivine $(\mathrm{Ol})$ in spinel pyroxenite (13008) from Nunivak Island, Alaska. Cpx: clinopyroxene, Spl: spinel. d. Spherical grain of sulfide in orthopyroxene in lherzolite (sample 10001) from Nunivak Island, Alaska. The large circle is engraved for analytical purposes. e. Veinlets containing primary sulfide along grain boundaries of olivine (Ol) in spinel lherzolite (sample 10057) from Nunivak Island, Alaska. The veinlet contains pyrrhotite and exsolution products of pentlandite and magnetite (Mag). f. Sulfide phases and ilmenite inclusions oriented within diopside megacryst in kimberlite from Frank Smith mine, South Africa (sample FS). Djr: djerfisherite, Po: pyrrhotite, Pn: pentlandite. Pentlandite, a product of exsolution of monosulfide solid-solution, rims the sulfide phase. The diopside host contains high $\mathrm{Mg}$ [atomic $\mathrm{Mg} /(\mathrm{Mg}+\mathrm{Fe})=0.87$ ], $\mathrm{Na}\left(1.68-1.78 w t \% \mathrm{Na}_{2} \mathrm{O}\right), \mathrm{Cr}(0.33-0.56$ wt $\left.\% \mathrm{Cr}_{2} \mathrm{O}_{3}\right)$ and $\mathrm{Ni}(390-890 \mathrm{ppm})$. 

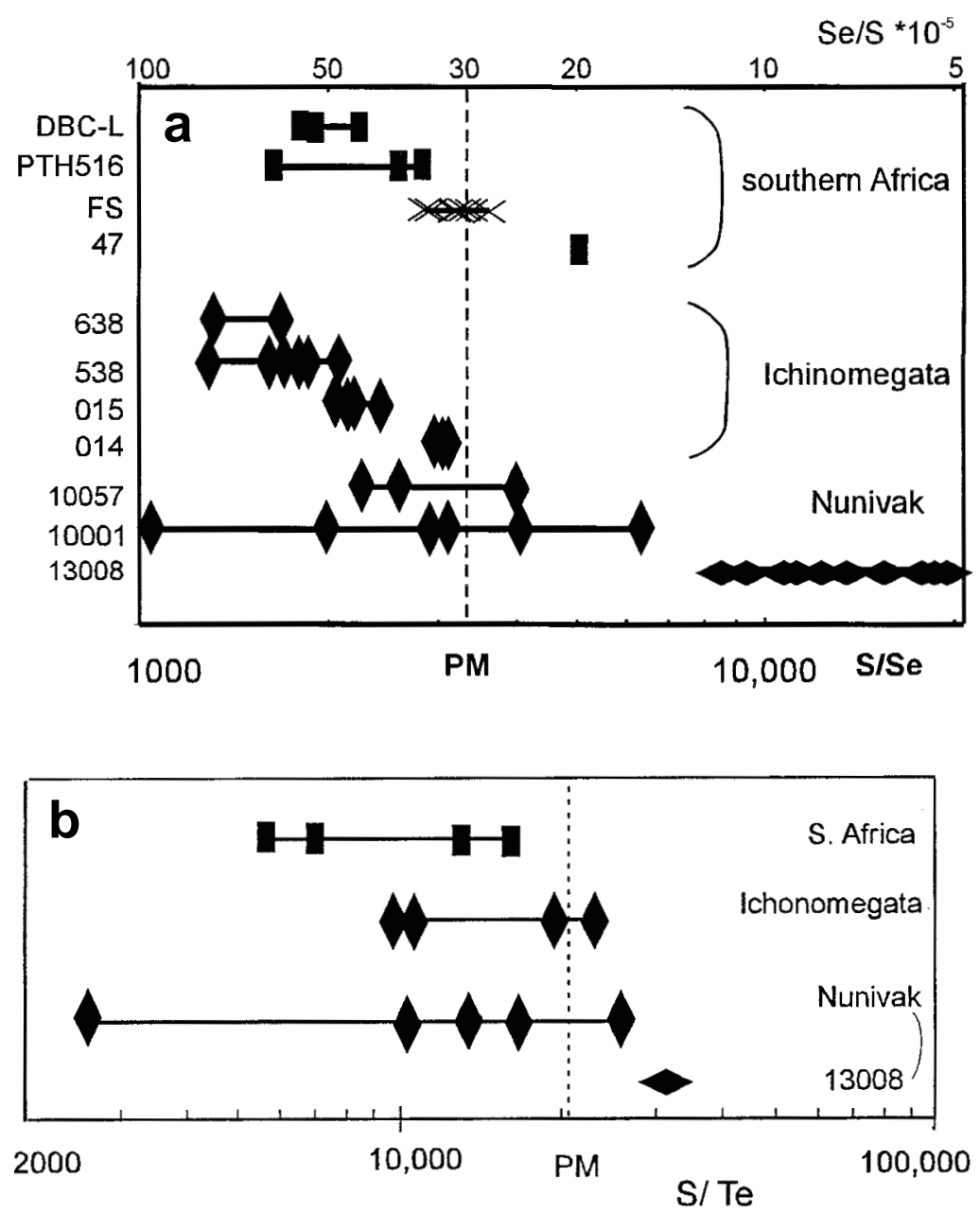

FIG. 2. a. Range of S/Se values in all samples. The ratio of primitive mantle (PM) calculated from the values given by McDonough \& Sun (1995) is shown by the dashed line. b. Range of S/Te values in all samples. Solid diamonds: samples from mantle wedges at Nunivak and Ichinomegata. Tall diamonds represent residues (lherzolite and harzburgite) and short tabular diamonds represent garnet clinopyroxenite (solidified melt in the mantle) from Nunivak Island. $\times$ : Sulfide associated with potassium sulfides in diopside megacryst in kimberlite. Squares: peridotite nodules in kimberlite.

As contents, 51 and $120 \mathrm{ppm}$, are reported from magnetic fractions of xenoliths, assumed to be sulfides, from Kilbourne Hole, New Mexico, and Dreiser Weiher, Germany (Jagoutz et al. 1979). High values are also noted in sulfide grains enclosed in diamond from samples showing of a peridotitic mineral assemblage (Bulanova et al. 1996).

With the analytical techniques used, antimony has high detection-limits ( 7 to $40 \mathrm{ppm}$ ). Furthermore, mantle sulfides are not expected to contain high concentrations of $\mathrm{Sb}$ because sulfides in the primitive mantle contain only $7 \mathrm{ppm} \mathrm{Sb}$ (Table 3). Thus only four grains from mantle wedges yielded detectable amounts of Sb, ranging from 9 to $146 \mathrm{ppm}$, and three grains from the subcontinental lithospheric mantle have Sb concentrations, ranging from 28 to $73 \mathrm{ppm}$.

\section{DisCUSSION}

Sulfide morphology, and the occurrence of sulfide liquid in the mantle

Sulfides in our samples are considered to have been liquid in the mantle, as sulfides of relevant composi- 


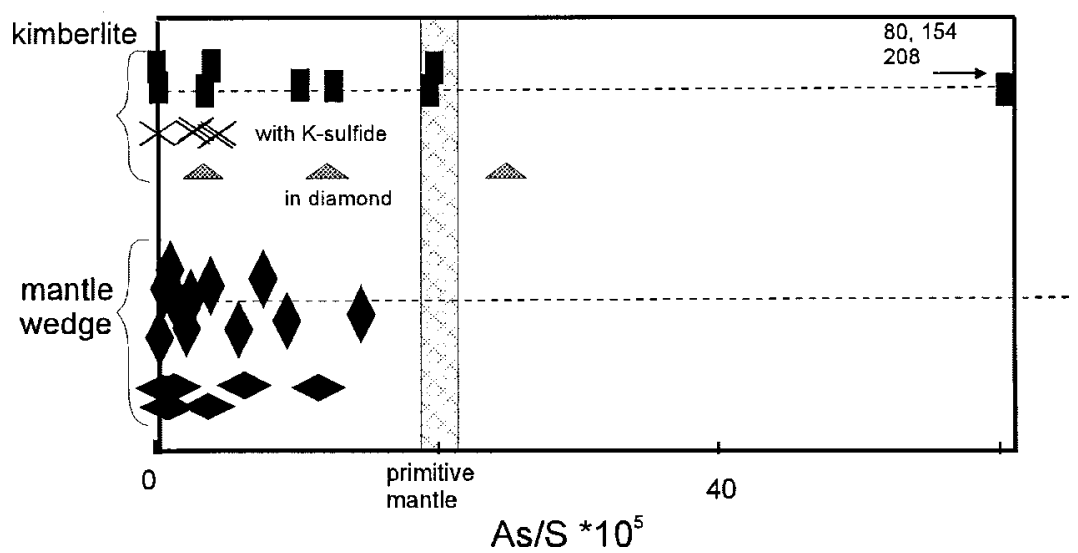

FIG. 3. Range of As/S values in sulfide grains. Symbols same as in Figure 2. Three sulfides grains with high As/S plot outside the range of the diagram and are indicated by an arrow.

tions are liquid even in the shallow crust, in magmas that are much cooler than the mantle (Czamanske \& Moore 1977, Francis 1990, Hattori 1993). The morphology of the sulfides in our samples is similar to that of sulfides in megacrysts at San Carlos, Arizona (Andersen et al. 1987) and Kilbourne Hole in New Mexico (Andersen et al. 1987, Dromgoole \& Pasteris 1987) and peridotitic mantle xenoliths in Hawaiian volcanic rocks (De Waal \& Calk 1974).

Experiments by Shannon \& Agee (1996) and Ballhaus \& Ellis (1996) suggest that the surface tension is large between sulfide liquid and silicates, whereas recent experiments by Gaetani \& Grove (1999) produced angular sulfides wetting the surface of olivine grains, leading them to suggest the presence of interconnected channels of sulfide liquid in the upper mantle. Secondary pyrrhotite forms veinlets along grain boundaries in silicates in serpentinized xenoliths, but such veinlets are very rare in unaltered xenoliths.

TABLE 3. CONCENTRATION OF Se, Te, As AND Sb IN PRIMITIVE MANTLE SULFIDE*

\begin{tabular}{lccc}
\hline & $\begin{array}{c}\text { Bulk primitive } \\
\text { mantle }(\mathrm{ppm})\end{array}$ & $\begin{array}{c}\text { Partition between } \\
\text { sulfide liquid } \\
\text { and silicate melt }\end{array}$ & $\begin{array}{c}\text { Primitive } \\
\text { mantle } \\
\text { sulfide }\end{array}$ \\
\hline $\mathrm{S}$ & $250(1)$ & & $36.4 \%$ \\
$\mathrm{Se}$ & $0.075(1)$ & $100,000(2)$ & $109 \mathrm{ppm}$ \\
$\mathrm{Te}$ & $0.012(1)$ & $100,000(2)$ & $17 \mathrm{ppm}$ \\
$\mathrm{As}$ & $0.05(1)$ & $1000(3)$ & $30 \mathrm{ppm}$ \\
$\mathrm{Sb}$ & $0.011(4)$ & $1250(3)$ & $7.4 \mathrm{ppm}$
\end{tabular}

Primitive mantle sulfide is defined as an immiscible sulfide liquid in the primitive mantle. References are given in parentheses; 1: McDonough \& Sun (1995), 2: Value of 100,000 is assigned for strongly chalcophile elements, 3: Klöch \& Palme (1988), 4: Jochum \& Hofmann (1997).
The rounded shapes of sulfide grains in our samples suggest that the interfacial energy between sulfide liquid and silicates in the mantle is large, and that sulfide liquid does not form interconnected thin films on the surfaces of silicate minerals there. First, the sulfide grains are commonly small, $<10 \mu \mathrm{m}$, but grains less than $1 \mu \mathrm{m}$ are not observed. Even grains along growth planes of diopside megacrysts are mostly greater than $1 \mu \mathrm{m}$ (Peterson \& Francis 1977). Second, a globular shape of sulfide grains is common along grain boundaries of silicate minerals. Angular sulfides thinly spread along silicate surfaces occur in only one sample. This morphological evidence suggests that sulfide liquids in the mantle do not wet silicate minerals to a significant degree. Sulfides are not connected to each other in the mantle. In addition, the compositional variation of sulfides, both within and between our samples, supports our petrographic observation, because interconnected sulfides would have a similar composition.

\section{S/Se and Se/Te values of the mantle}

Nickel is a compatible element in olivine, and is enriched in the mantle during partial melting. It is likely that $\mathrm{Ni}$ contents in sulfides in the mantle increased in response to increasing $\mathrm{Ni}$ in silicate minerals, judging from rapid equilibration between silicate minerals and sulfide liquid in the short-duration experiments (Gaetani \& Grove 1997). Therefore, the inverse relationship between $\mathrm{Ni}$ and $\mathrm{S} / \mathrm{Se}$ in the sub-arc mantle rocks (Fig. 4) suggests that $\mathrm{Se}$ is preferentially retained in the mantle during partial melting. Our data confirm this intuitive interpretation (Fig. 4). Except for the "melt" sample (13008) from Nunivak Island, the S/Se values are significantly lower than that of primitive mantle and those from mid-oceanic ridge basalts (MORB; Peach et al. 1990) (Fig. 4). 


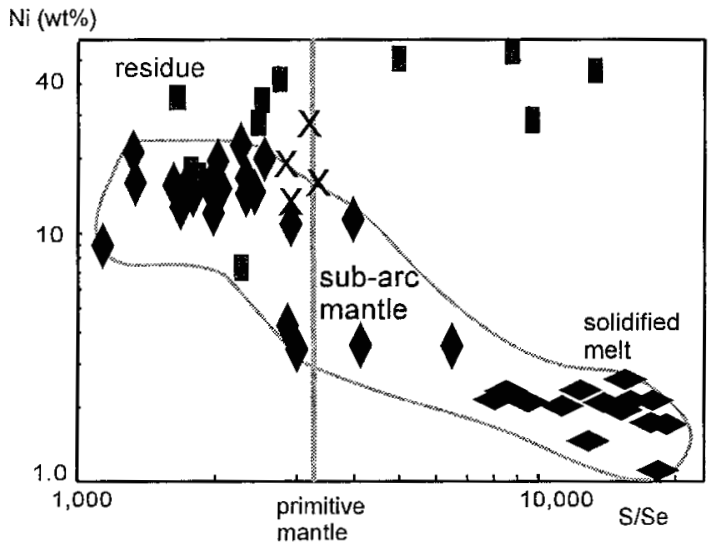

FIG. 4. Concentrations of $\mathrm{Ni}$ and $\mathrm{S} / \mathrm{Se}$ values in all samples. Primitive mantle value is from McDonough \& Sun (1995).

The Se/Te values range from 6 to 11 in the Ichinomegata samples, 2.3 in the Nunivak sample, and 2.2 to 4.2 in the subcontinental lithosphere samples (Fig. $5)$. The $\mathrm{Se} / \mathrm{Te}$ values of all sulfide samples are comparable to the value for primitive mantle (6.3: McDonough $\&$ Sun 1995), but are distinctly lower than the values for MORB (Hertogen et al. 1980) and for Hawaiian and Columbian River flood basalts (BHVO-1 and BCR-1; Govindaraju 1994). The lower Se/Te values in the mantle compared to basalt suggest that $\mathrm{Te}$ is probably retained in the mantle.

Selenium and tellurium should behave coherently with $\mathrm{S}$ in the generally reduced mantle, but our data indicate considerable fractionation of these elements. Possible causes for the fractionation in the mantle include:

(1) Sulfate formation: Sulfate minerals contain low concentrations of Se (Badalov et al. 1969), and oxidation of sulfide to form soluble sulfate is the principal cause for the variation in $\mathrm{S} / \mathrm{Se}$ values in surface environments (e.g., Stanton 1972). The common occurrence of anhydrite in arc magmas appears to support this possibility, but anhydrite in young volcanic rocks is a product of degassing at crustal levels (Hattori 1993). Although sub-arc mantle may be relatively oxidized (Wood et al. 1990), there is no evidence for the formation of sulfate in sub-arc mantle. Therefore, we discount this possibility.

(2) Addition of S from subducting slabs: Dehydration of subducting slabs discharge volatile elements into overlying mantle wedges, among which is $\mathrm{S}$ (e.g., Alt et al. 1993). The variation in $\mathrm{S} / \mathrm{Se}$ in our samples may be attributed to a contribution of crustal S through subduction. Ocean sulfate contains low Se (Measures et al. 1980), and marine pelagic sediments are generally low in Se, except for organic-matter-rich black shales (Stanton 1972). Therefore, a contribution of S from subducting sediments to the mantle wedge would generally

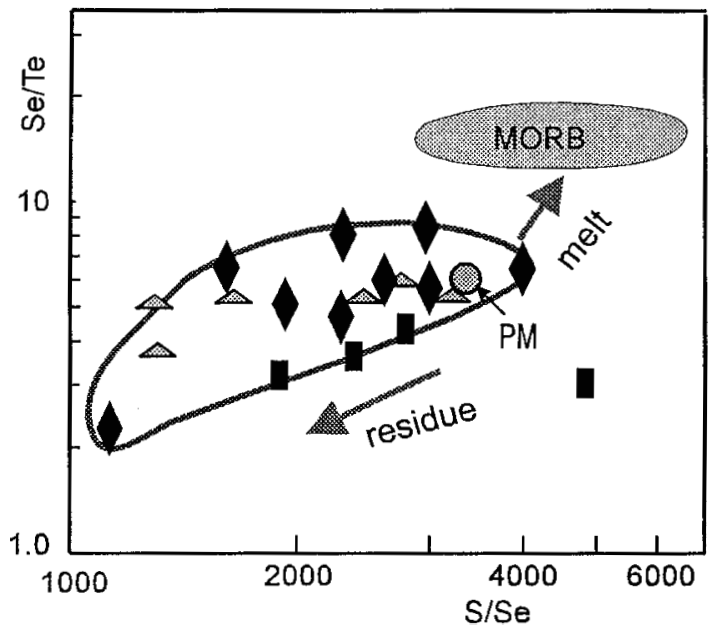

FIG. 5. S/Se and Se/Te values of sulfides from mantle rocks. Symbols same as those in Figure 2. The data on sulfides enclosed by diamonds in peridotitic assemblages with no apparent fractures (shown as solid triangles) are from Bulanova et al. (1996). Data on mid-ocean-ridge basalts (MORB) from Hertogen et al. (1980), Hamlyn \& Keays (1986) and Peach et al. (1990).

increase the $\mathrm{S} / \mathrm{Se}$ value. The overall low $\mathrm{S} / \mathrm{Se}$ values of most sulfides in our samples do not support a significant contribution of marine $\mathrm{S}$ to mantle wedges via subduction.

(3) Fractionation of S, Se and Te during partial melting in the mantle: High Se/Te values in MORB compared to mantle rocks suggest preferential enrichment of Se in melt and retention of Te in the mantle (Hertogen et al. 1980). High S/Se values in MORB glass (Peach et al. 1990) compared to mantle rocks suggest that $S$ is preferentially enriched in melt during partial melting. The low S/Se values (666-2500) in obducted refractory mantle rocks (Garuti et al. 1984) seem to support this idea. These studies suggest that the relative preferential removal of elements from the mantle is: $\mathrm{S}>\mathrm{Se}>\mathrm{Te}$.

This proposed interpretation is consistent with low $\mathrm{S} / \mathrm{Se}$ values in the most refractory spinel harzburgite (sample 638) from Ichinomegata and harzburgite from subcontinental lithospheric mantle (sample DBC-2631 ). It is also consistent with high concentrations of $\mathrm{Te}(>30 \mathrm{ppm})$ in sulfide grains in the spinel harzburgite from Ichinomegata. Therefore, we conclude that partial melting resulted in the fractionation of $\mathrm{S}, \mathrm{Se}$ and $\mathrm{Te}$ in the mantle.

Sulfides in peridotitic xenoliths from kimberlites show a wide range in S/Se (1600 to 9750), but the values are mostly lower than the primitive mantle value (Fig. 2), suggesting a previous episode of melting in the subcontinental lithospheric mantle, from which the 


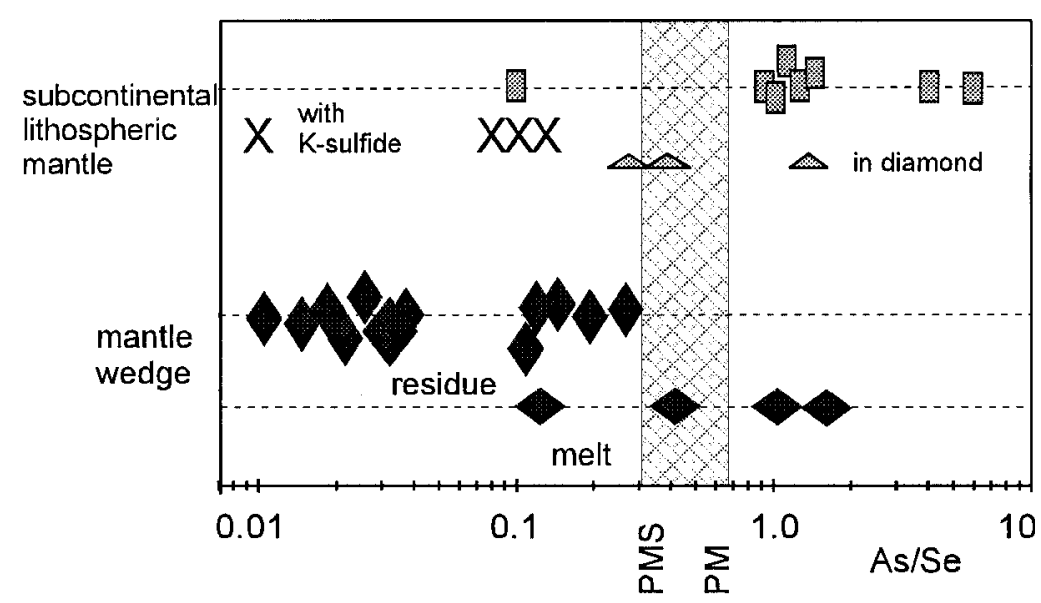

FIG. 6. Range of As/Se values of all sulfide grains sampled. Symbols same as in Figure 5. The values of As/Se in primitive mantle (PM) and primitive mantle sulfide (PMS) are listed in Table 3 .

xenoliths were derived. Our data are consistent with numerous studies indicating the highly refractory nature of the subcontinental lithospheric mantle underlying the Kaapvaal craton (e.g., Pearson et al. 1995).

Our data imply that the S/Se value of a mantlederived magma may vary depending on that of the source. S/Se values of approximately 3,000 have been used as mantle signatures of $\mathrm{S}$ for magmatic Ni sulfide deposits (e.g., Eckstrand et al. 1989, Maier \& Barnes 1999). Sedimentary rocks generally contain low Se (Stanton 1972) and S may be preferentially lost from the rocks during thermal events. Thus, departure from the "mantle value" of $\mathrm{S} / \mathrm{Se}$ is considered to indicate assimilation of sedimentary rocks (e.g., Ripley 1990) or later modification of sulfides through a variety of mechanisms, such as loss of $\mathrm{S}$ during solidification (Brügmann et al. 1990), modification of Se/S value during sulfide formation (Maier \& Barnes 1999), subsolidus alteration (Peck \& Keays 1990), or loss of S during regional metamorphism (Maier \& Barnes 1996). However, the compilation of data from a variety of "pristine" magmatic sulfide ores by Eckstrand et al. (1989) shows considerable variation in S/Se values. Our work suggests that at least some of the variation in $\mathrm{S} / \mathrm{Se}$ in sulfide ores likely reflects the source mantle. Magmas derived from refractory mantle would have low S/Se values. Our proposed interpretation is supported by high levels of Se compared to $\mathrm{S}, \mathrm{S} / \mathrm{Se}<400$, in many boninite rocks (e.g., Hamlyn et al. 1985, Peck \& Keays 1990, Peck et al. 1992), which form by high degrees of melting of a refractory mantle in a supra-subduction-zone environment.

\section{Low As and Sb in the mantle wedge}

The relatively high abundance of As in sulfides reflects a high concentration of As ( 30 ppm) in the hypothetical primitive mantle sulfide (Table 3 ). The composition of this primitive mantle sulfide was calculated using the concentration of elements in the primitive mantle (McDonough \& Sun 1995), and partition coefficients of the elements between silicate and sulfide melt (Table 3), assuming that $\mathrm{S}$ in the primitive mantle was present as sulfide.

Arc magmas are commonly enriched in $\mathrm{As}$ and $\mathrm{Sb}$ (Noll et al. 1996) and many metallic deposits in arcs contain high As and Sb (e.g., Stanton 1972). The enrichment has been explained by the supply of these elements from subducting slabs to sub-arc mantle through mantle metasomatism. We, therefore, anticipated high $\mathrm{As}$ and $\mathrm{Sb}$ in sulfides from mantle wedges, but most grains contain low As (Figs. 5, 6). Our results are consistent with low contents of the two elements in bulk-rock samples of spinel lherzolite xenoliths (Jagoutz et al. 1979, Kurat et al. 1980).

If these elements are indeed supplied to arc magmas from subducting slabs (Noll et al. 1996), our low concentrations of $\mathrm{As}$ and $\mathrm{Sb}$ in mantle sulfides suggest that these elements have short residence-times in mantle wedges, or that scavenging of these elements by hydrous partial melt in mantle wedges is effective. It is also possible that these elements were directly transferred from fluids to partial melt without residing in the mantle wedges. 


\section{Fractionation of As and $S b$}

Antimony and As are expected to behave coherently in the mantle because these two elements have the same charge (+5; Hertogen et al. 1980) and similar ionic radii. Therefore, partial melting and solidification of the melt should not fractionate the two elements. However, our data show a large range in $\mathrm{Sb} / \mathrm{As}$ values. The sulfide grain in olivine from the garnet lherzolite in kimberlite from Pipe 200, Lesotho (sample DBC26-31) has an $\mathrm{Sb} / \mathrm{As}$ value of 0.12 , the same as is expected for primitive mantle sulfide (Table 3 ). Grains from Ichinomegata and Nunivak show much higher Sb/As values, 4.1 and 2.4, respectively. High values suggest either an enrichment of Sb or a depletion of As. These Sb-bearing grains have low As/S values, 8 and $4 \times$ $10^{-5}$, compared with the primitive mantle value of $20 \times$ $10^{-5}$ (McDonough \& Sun 1995) to $33 \times 10^{-5}$ (Taylor $\&$ McLennan 1985). Their Sb/S values are high, 37 and $8 \times 10^{-5}$, compared with $2.2 \times 10^{-5}$ in the primitive mantle (McDonough \& Sun 1995). These data suggest that the two sub-arc samples underwent As depletion and $\mathrm{Sb}$ enrichment.

Because As and $\mathrm{Sb}$ behave coherently in magmatic processes, we attribute the separation of the two elements to fluid transport. Both As and Sb are soluble in high-temperature aqueous fluids, and $\mathrm{Sb}$ is particularly mobile (Jochum \& Verma 1996). The proposed interpretation, fluid transport of $\mathrm{As}$ and $\mathrm{Sb}$ in the sub-arc mantle, is supported by the composition of Sb-bearing sulfides. The high-Sb (146 ppm) sulfide in pargasite lherzolite from Ichinomegata contains $8 \mathrm{ppm} \mathrm{Ag}$ and $16 \mathrm{ppm} \mathrm{Re}$, and other sulfide grains in the same section contain $\mathrm{Sb}$ below detection limits, although the morphology and textures of these $\mathrm{Sb}$-bearing and $\mathrm{Sb}$-poor sulfides are very similar. The Sb-bearing (30 ppm) sulfide from Nunivak Island also is rich in Ag (14 ppm).

Our data suggest that Sb-bearing fluids did not interact with all sulfide grains. The evidence is in accord with vein-like occurrences of phlogopite and pargasite in mantle xenoliths and compositional variation of amphibole, a product of hydration, in sub-arc mantle (Abe et al. 1992, 1998, Francis 1976).

\section{Residual sulfide in refractory mantle?}

Refractory mantle rocks contain low concentrations of incompatible elements in silicate minerals because these elements are preferentially removed by partial melts. Sulfur, one such element, is believed to be low in the mantle residue because $S$ has a high solubility in mafic melts (e.g., Wendlandt 1982). Essential absence of $\mathrm{S}$ in the residual mantle is supported by consistent $\mathrm{Ce} / \mathrm{Pb}$ (Newsom et al. 1986 ) and $\mathrm{Sb} / \mathrm{Pr}$ values (Jochum \& Hofmann 1997) in oceanic basalts. Where $S$ is not present, $\mathrm{Pb}$ and $\mathrm{Sb}$ behave like ordinary lithophile incompatible elements during igneous processes. Therefore, these pairs, $\mathrm{Ce} / \mathrm{Pb}$ and $\mathrm{Sb} / \mathrm{Pr}$, are similar among igneous rocks. If $\mathrm{S}$ is present in the mantle, $\mathrm{Pb}$ and $\mathrm{Sb}$ would be retained in the mantle sulfide, and values of these ratios would change. These geochemical data for volcanic rocks suggest that essentially no sulfur should remain in the refractory mantle.

However, abundant petrographic evidence suggests that sulfur is still present in the residual mantle. MORBs are saturated with $\mathrm{S}$, producing sulfide droplets in quenched glass (e.g., Czamanske \& Moore 1977, Francis 1990). Arc magmas derived from highly refractory mantle wedges are saturated with S (e.g., Hattori 1993). Many arc volcanoes discharge enormous amounts of S gases (e.g., Bluth et al. 1992). This apparently contradictory evidence may be attributed to the retention of sulfides protected by refractory silicate minerals during partial melting (Hart \& Ravizza 1996), or by the replenishment of $\mathrm{S}$ from external sources such as slabs (e.g., Alt et al. 1993) and the deep mantle. Sulfur may be replenished from deep mantle to sulfur-poor areas through interconnected sulfide liquid (e.g., Gaetani \& Grove 1999). The latter two possibilities are rejected by our limited data because $S$ from slabs is characterized by high $\mathrm{S} / \mathrm{Se}$ and because $\mathrm{S}$ from a deep fertile mantle should have a chondritic $S / S e$ value. Therefore, $\mathrm{S}$ replenished by subducting slabs and from a deep fertile mantle should have a high $\mathrm{S} / \mathrm{Se}$ value. This mechanism is not consistent with our data. Sulfide samples from sub-arc mantle show low $\mathrm{S} / \mathrm{Se}$ and $\mathrm{Se} / \mathrm{Te}$ values.

Sulfur in arc magmas may be efficiently scavenged from mantle wedges or supplied directly from subducting slabs without residing in mantle wedges.

\section{Conclusions}

Sulfur, Se and Te are fractionated in the mantle, i.e., they do not behave coherently. Se/Te and S/Se values of sulfide grains from mantle wedges beneath arcs are generally lower than the inferred value of primitive mantle sulfide. Sulfides in the subcontinental lithospheric mantle also are depleted in S, similar to those in mantle wedges, reflecting a previous extraction of melt. Values of S/Se close to 3,300 are commonly viewed as being typical of mantle-derived magmas, but these may show a variation in the values reflecting the previous melting history of the mantle.

Arsenic and $\mathrm{Sb}$ are removed from the mantle during partial melting, leading to low concentrations in sulfide in refractory mantle. Erratically high values in the mantle wedges and from peridotite nodules in kimberlites are attributed to fluid transport of these elements during mantle metasomatism.

Enrichment of $\mathrm{As}, \mathrm{Sb}$ and $\mathrm{S}$ in arc magmas generally are believed to reflect their enrichment in mantle wedges. We did not find any evidence of such enrichment in mantle wedges. These elements may be efficiently removed from mantle wedges by hydrated arc magmas. Alternatively, these elements may have been 
transferred by aqueous fluid from slabs to arc magmas without residing in the mantle.

\section{ACKNOWLEDGEMENTS}

We dedicate this paper to Louis J. Cabri, a pioneer in the application of the PIXE technique to mineralogical investigations. This study was supported by NSERC Research grants to $\mathrm{KHH}$ and $\mathrm{DBC}$, and by the Ministry of Education and Science to AS. KHH thanks Don Francis for providing samples from Nunivak Island, Peter Jones of Carleton University for his assistance with SEM analysis, and William Teesdale of Guelph University for his help during the PIXE analysis. We thank two anonymous reviewers and Robert F. Martin for their helpful comments.

\section{REFERENCES}

ABE, N. \& Arai, S. (1993): Petrographical characteristics of ultramafic xenolliths from Megata volcano, the Northeast Japan arc. Sci. Rep. Kanazawa Univ. 38, 1-24.

\& SAEKI, Y. (1992): Hydration processes in the arc mantle; petrology of the Megata peridotite xenoliths, the Northeast Japan arc. J. Mineral. Petrol. Econ. Geol. 87, 305-317.

\& Yurimoto, H. (1998): Geochemical characteristics of the uppermost mantle beneath the Japan island arcs; implications for upper mantle evolution. Phys. Earth Planet. Int. 107, 233-248.

Alt, J.C., Shanks, W.C., III. \& JaCKson, M.C. (1993): Cycling of sulfur in subduction zones: the geochemistry of sulfur in the Mariana Island arc and back-arc trough. Earth Planet. Sci. Lett. 119, 477-494.

Andersen, T., Griffin, W.L. \& O'Reilly, S.Y. (1987): Primary sulphide melt inclusions in mantle-derived megacrysts and pyroxenites. Lithos 20, 279-294.

ARAI, S. (1986): K/Na variation in phlogopite and amphibole of upper mantle peridotites due to fractionation of the metasomatic fluids. J. Geol. 94, 436-444.

Arculus, R.J. \& Delano, J.W. (1981): Siderophile element abundances in the upper mantle: evidence for a sulfide signature and equilibrium with the core. Geochim. Cosmochim. Acta 45, 1331-1343.

Badalov, S.T., Belopol'skaya, T.L., Prikhid'ko, P.L \& TuRESEBEKOV, A. (1969): Geochemistry of selenium in sulfate-sulfide mineral parageneses. Geochem. Int., 799-802.

Ballhaus, C. \& Ellis, D.J. (1996): Mobility of core melts during Earth's accretion. Earth Planet. Sci. Lett. 143, 137-145.

Bluth, G.J.S., Doiron, S.D., Schnetzler, C.C., Krueger, A.J. \& WALTER, L.S. (1992): Global tracking of the $\mathrm{SO}_{2}$ clouds from the June, 1991 Mount Pinatubo eruptions. Geophys. Res. Lett. 19, 151-154.

Brügmann, G.E., Naldrett, A.J. \& Duke, J.M. (1990): The platinum-group element distribution in the Dumont sill, Québec. Implications for the formation of Ni-sulphide mineralization. Mineral. Petrol. 42, 97-119.

Bulanova, G.P., Griffin, W.L., Ryan, C.G., Shestakova, O.Y. \& BARNES, S.J. (1996): Trace elements in sulfide inclusions from Yakutian diamonds. Contrib. Mineral. Petrol. 124, 111-125.

Cabri, L.J., Blanck, H., El Goresy, A., LaFlamme, J.H.G., Nobiling, R., Sizgoric, M.B. \& TraXel, K. (1984): Quantitative trace-element analyses of sulfides from Sudbury and Stillwater by proton microprobe. Can. Mineral. 22,.521-542.

Campbell, J.L. \& Czamanske, G.K. (1998): Micro-PIXE in Earth Science. Rev. Econ. Geol. 7, 169-185.

Carswell, D.A., Clarke, D.B. \& Mitchell, R.H. (1979): The petrology and geochemistry of ultramafic nodules from Pipe 200, northern Lesotho. Proc. Second Int. Kimberlite Conf. 2, 127-144.

Clarke, D.B., Pe, G.G., MacKay, R.M., Gill, K.R., O'Hara, M.J. \& GARD, J.A. (1977): A new potassium-iron-nickel sulfide from a nodule in kimberlite. Earth Planet. Sci. Lett. 35, 421-428.

Czamanske, G.K. \& Moore, J.G. (1977): Composition and phase chemistry of sulfide globules in basalt from the MidAtlantic Ridge rift valley near $37^{\circ}$ N. Geol. Soc. Am., Bull. 88, 587-599.

De WaAl, S.A. \& CALK, L.C. (1974): The sulfides in the garnet pyroxenite xenoliths from Salt Lake Crater, Oahu. $J$. Petrol. 16, 134-153.

Dreibus, G., Palme, H., Spettel, B., Zipfel, J. \& WÄnke, H. (1995): Sulfur and selenium in chondritic meteorites. Meteoritics 30, 439-445.

Dromgoole, E.L. \& PASTERIS, J.D. (1987): Interpretation of the sulfide assemblages in a suite of xenoliths from Kilbourne Hole, New Mexico. In Mantle Metasomatism and Alkaline Magmatism (E.M. Morris \& J.D. Pasteris, eds.). Geol. Soc. Am., Spec. Pap. 215, 25-46.

Eckstrand, O.R., Grinenko, L.N., Krouse, H.R., PaKtunc, A.D. SchwanN, P.L. \& Scoates, R.F.J. (1989): Preliminary data on sulphur isotopes and $\mathrm{Se} / \mathrm{S}$ ratios, and the source of sulphur in magmatic sulphides from the Fox River Sill, Molson Dykes and Thompson nickel deposits, northern Manitoba. Geol. Surv. Can., Pap. 89-C, 235-242.

FRANCIS, D.M. (1976): The origin of amphibole in lherzolite xenoliths from Nunivak Island, Alaska. J. Petrol. 17, 357-378.

(1978): The implications of the compositional dependence of texture in spinel lherzolite xenoliths. $J$. Geol. 86, 473-485. 
FRANCIS, R.D. (1990): Sulfide globules in mid-ocean ridge basalts (MORB), and the effect of oxygen abundance in $\mathrm{Fe}-\mathrm{S}-\mathrm{O}$ liquids on the ability of those liquids to partition metals from MORB and komatiite magmas. Chem. Geol. 85, 199-213.

Gaetani, G.A. \& Grove, T.L. (1997): Partitioning of moderately siderophile elements among olivine, silicate melt, and sulfide melt; constraints on core formation in the Earth and Mars. Geochim. Cosmochim. Acta 61, 1829-1846.

\& (1999): Wetting of mantle olivine by sulfide melt: implications for Re/Os ratios in mantle peridotite and late-stage core formation. Earth Planet. Sci. Lett. 169, 147-163.

Garuti, G., Gorgani, C. \& Sighinolfi, G.P. (1984): Sulfide mineralogy and chalcophile and siderophile element abundances in the Ivrea-Verbano mantle peridotites (western Italian Alps). Earth Planet. Sci. Lett. 70, 69-87.

GovindARAJU, K. (1994): Compilation of working values and sample description for 383 geostandards. Geostandards Newsletter 18, 1-159.

HAMLYN, P.R. \& KEAYs, R.R.(1986): Sulfur saturation and second-stage melts: application to the Bushveld platinum metal deposits. Econ. Geol. 81, 1431-1445.

Cameron, W.E., Crawford, A.J. \& WALDRON, H.M. (1985): Precious metals in magnesian low-Ti lavas; implications for metallogenesis and sulfur saturation in primary magmas. Geochim. Cosmochim. Acta 49, 1797-1811.

HART, S.R. \& RAvizZA, G.E. (1996): Os partitiotning between phases in mantle lherzolite. Geophys. Monogr. 95, 123-134.

HATTORI, K. (1993): High-sulfur magma, a product of fluid discharge from underlying mafic magma: evidence from Mount Pinatubo, Philippines. Geology 21, 1083-1086.

Hertogen, J., Janssens, M.-J. \& Palme, H. (1980): Trace elements in ocean ridge basalt glasses: implications for fractionations during mantle evolution and petrogenesis. Geochim. Cosmochim. Acta 44, 2125-2143.

Jagoutz, E., Palme, H., Baddenhausen, H., Blum, K., Cendales, M., Dreibus, G., Spettel, B., Lorenz, V. \& WÄNKE, H. (1979): The abundances of major, minor, and trace elements in the Earth's mantle as derived from primitive ultramafic nodules. Proc. Lunar Planet Sci. Conf. 10, 2031-2050.

Jochum, K.P. \& HofmanN, A.W. (1997): Constraints on Earth evolution from antimony in mantle-derived rocks. Chem. Geol. 139, 39-49.

\& Verma, S.P. (1996): Extreme enrichment of Sb, $\mathrm{Tl}$ and other trace elements in altered MORB. Chem. Geol. 130, 289-299.
KLÖCK, W. \& PALme, H. (1988): Partitioning of siderophile and chalcophile elements between sulfide, olivine, and glass in a naturally reduced basalt from Disko Island, Greenland. Proc. Lunar Planet. Sci. Conf. 18, 471-483.

Kumar, N., Reisberg, L. \& Zindler, A. (1996): A major and trace element and strontium, neodymium, and osmium isotopic study of a thick pyroxenite layer from the Beni Bousera ultramafic complex of northern Morocco. Geochim. Cosmochim. Acta 60, 1429-1444.

Kuno, H. (1967): Mafic and ultramafic nodules from Itinomegata, Japan. In Ultramafic and Related Rocks (P.J. Wyllie ed.). John Wiley \& Sons, New York, N.Y. (337-342).

Kurat, G., Palme, H., Spettel, B., Baddenhausen, H., Hofmeister, H., Palme, C. \& Wänke, H. (1980): Geochemistry of ultramafic xenoliths from Kapfenstein, Austria: evidence for a variety of upper mantle processes. Geochim. Cosmochim. Acta 44, 45-60.

MAIER, W.D. \& BARNES, S.-J. (1996): Unusually high concentrations of magnetite at Caraiba and other $\mathrm{Cu}$-sulfide deposits in the Curaçá Valley, Bahia, Brazil. Can. Mineral. 34, 717-731.

\& ___ (1999): The origin of Cu sulfide deposits in the Curaçá Valley, Bahia, Brazil: evidence from $\mathrm{Cu}$, $\mathrm{Ni}, \mathrm{Se}$ and platinum-group element concentrations. Econ. Geol. 94, 165-183.

McDonough, W.F. \& Sun, Shen-Su (1995): The composition of the Earth. Chem. Geol. 120, 223-253.

Measures, C.I., McDuff, R.E. \& EdMOND, J.M. (1980): Selenium redox chemistry at Geosecs. I. Re-occupation. Earth Planet. Sci. Lett. 49, 102-108.

Mitchell, R.H., Carswell, D.A. \& Clarke, D.B. (1980): Geological implications and validity of calculated equilibration conditions for ultramafic xenoliths from the Pipe 200 kimberlite, northern Lesotho. Contrib. Mineral. Petrol. 72, 205-217.

Newsom, H.E., White, W.M., Jochum, K.P. \& Hofmann, A.W. (1986): Siderophile and chalcophile element abundances in oceanic basalts, $\mathrm{Pb}$ isotope evolution and growth of the Earth's core. Earth Planet. Sci. Lett. 80, 299313.

Noll, P.D., JR., Newsom, H.E., Leeman, W.P. \& Ryan, J.G. (1996): The role of hydrothermal fluids in the production of subduction zone magmas: evidence from siderophile and chalcophile trace elements and boron. Geochim. Cosmochim. Acta 60, 587-611.

PAlme, H. (1999): Earth's formation and geochemical evolution. In Encyclopedia of Geochemistry (C.P.Marshall \& R.W. Fairbridge, eds.). Kluwer Academic, New York, N.Y. (156-162).

Peach, C.L., Mathez, E.A. \& Keays, R.R. (1990): Sulfide melt - silicate melt distribution coefficients for noble metals and other chalcophile elements as deduced from 
MORB: implications for partial melting. Geochim. Cosmochim. Acta 54, 3379-3389.

Pearson, D.G., Carlson, R.W., Shirey, S.B., Boyd, F.R. \& NixON, P.H. (1995): Stabilization of Archean lithospheric mantle - a Re-Os isotope study of peridotite xenoliths from the Kaapvaal craton. Earth Planet. Sci. Lett. 134, 341-357.

PECK, D.C. \& KEAYs, R.R. (1990): Insights into the behavior of precious metals in primitive, S-undersaturated magmas; evidence from the Heazlewood River Complex, Tasmania. Can. Mineral. 28, 553-577.

\& FORD, R.J. (1992): Direct crystallization of refractory platinum-group element alloys from boninitic magmas; evidence from western Tasmania. Aust. J. Earth Sci. 39, 373-387.

Peterson, R. \& Francis, D.M. (1977): The origin of sulfide inclusions in pyroxene megacrysts. Am. Mineral. 62 1049-1051.

RAma Murthy, V. (1991): Early differentiation of the Earth and the problem of mantle siderophile elements: a new approach. Science 253, 303-306.

RIPLEY, E.M. (1990): Se/S ratios of the Virginia formation and $\mathrm{Cu}-\mathrm{Ni}$ sulfide mineralization in the Babbitt area, Duluth Complex, Minnesota. Econ. Geol. 85, 1935-1940.

Roden, M.F., Frey, F.A. \& Francis, D.M. (1984): An example of consequent mantle metasomatism in peridotite inclusions from Nunivak Island, Alaska. J. Petrol. 25, 546-577.

Rose, L.A. \& BrenAN, J.M. (2001): Wetting properties of Fe$\mathrm{Ni}-\mathrm{Co}-\mathrm{Cu}-\mathrm{O}-\mathrm{S}$ melts against olivine; implications for sulfide melt mobility. Econ. Geol. 96, 145-157.

Roy-Barman, M., Wasserburg, G.J., Papanastassiou, D.A. \& Chaussidon, M. (1998): Osmium isotopic compositions and Re-Os concentrations in sulphide globules from basaltic glasses. Earth Planet. Sci. Lett. 154, 331-347.
SchandL, E. (1980): Evolution of the Phlogopite - Chrome Diopside - Spinel Pools in the Ultramafic Nodules of Pipe 200, Northern Lesotho. B.Sc. thesis, Dalhousie Univ., Halifax, Nova Scotia.

Shannon, M.C. \& AgEe, C.B. (1996): High pressure constraints on percolative core formation. Geophys. Res. Lett. 23, 2717-2720.

Sillitoe, R.H. (1972): A plate tectonic model for the origin of porphyry copper deposits. Econ. Geol. 67, 184-197.

Stanton, R.L. (1972): Ore Petrology. McGraw-Hill, New York, N.Y.

Sun, SHEN-Su (1985): Multistage accretion and core formation of the Earth. Nature 313, 628-629.

TAKAHASHI, E. (1986): Genesis of calc-alkali andesite magma in a hydrous mantle-crust boundary: petrology of lherzolite xenoliths from the Ichinomegata crater, Oga Peninsula, northeast Japan, II. J. Volcanol. Geotherm. Res. 29, 355-395.

TAYloR, S.R. \& McLennan, S.M. (1985): The Continental Crust: Its Composition and Evolution. Blackwell Sci. Publ., Oxford, U.K.

WENDLANDT, R.F. (1982): Sulfide saturation of basalt and andesite melts at high pressures and temperatures. Am. Mineral. 67, 877-885.

Wood, B.J., BRYNDZia, L.T. \& Johnson, K.E. (1990): Mantle oxidation state and its relationship to tectonic environment and fluid speciation. Science 248, 337-345.

Received September 8, 2000, revised manuscript accepted August 25, 2001. 